\title{
Will the Holocaust Please Hush? Social and Historical Incongruity in Savyon Liebrecht's Hayuta’s Engagement Party
}

\author{
Corinne E. Blackmer \\ Southern Connecticut State University
}

\begin{abstract}
Mendel, a survivor of Auschwitz who lives in Israel, remains silent for forty years after his traumatic experiences. However, Mendel, for no reason that his daughter Bella, also a survivor, can discern, begins to testify to his horrific ordeals during the Holocaust at putatively inopportune times, such as religious holidays and family celebrations. When his granddaughter Hayuta plans an engagement party, the social and historical incongruities of the Holocaust in the context of contemporary Israeli society become apparent. Ordinary pleasures are matters of moral obloquy in the face of the unfathomable black hole of the Holocaust. While critics have charged Mendel's daughter with preoccupation with invidious social climbing and his granddaughter Hayuta with moral reprehensible compartmentalization of her historical and familial existences, Liebrecht unwittingly implies that historical trauma has very diverse and inexplicable effects on different family members: Some, like the daughter Bella, eventually wish to hear more about the experiences of her father (while feeling that his words will "ruin" her social life), while Hayuta and Shifra his daughter-in-law react by shunning the speech of Mendel, which they experience as destroying their quotidian happiness.
\end{abstract}

Keywords: Liebrecht Savyon, Holocaust, intergenerational PTSD, traumatic testimonial, Jewish history, Israel, remembrance

\section{Introduction}

Few things represent such ordinary yet privately meaningful celebrations an engagement parties. Social custom decrees that all guests adopt a demeanor of cheer, and focus on the future happiness of the prospective bride and, traditionally, groom. On the other hand, few - if any - things represent such an extraordinary and world-transformative public tragedy as the Holocaust, where over six million Jews lost their lives because of the Nazi's pursuit of the Final Solution. Indeed, the Holocaust represents a horror of such magnitude as to continue to elude most attempts to characterize or speak about it coherently. The Holocaust often is, especially for individual survivors and survivors' descendants, traumatically unspeakable.

This problem of muteness is not only acute for survivors, who, frequently, neither wish to remember nor to relate the vast terror that giving testimonies to their experiences would cause them, but also for listeners, who vicariously experience the trauma and, with their witnessing, transform the trauma into testimony. Why then give utterance to such testimonies or relive such unspeakable pain? The principal answer that Jewish writers and philosophers such as Elie Wiesel, Emanuel Levinas, and Emil Fackenheim, among others, have given centers on the conviction that we must remember, record—and, above all, learn from — the Holocaust. Recalled 
properly - through ethically responsible testimony and witnessing-returning to the Holocaust holds out the hope that humanity will never again repeats this unprecedented historical calamity, plausibly deny that the Holocaust occurred, or, for Fackenheim, declare that the Holocaust has rendered Torah, the Covenant, and belief in the Jewish God dead.

However, these and other august pieties about the relationships between historical memories of the Holocaust and present day life are odds in this humane, ironically absurdist, and tragicomic short story set in a contemporary Jewish Israeli social milieu. Specifically, in Hayuta’s Engagement Party (1986), Savyon Liebrecht interrogates the considerable challenges involved in learning from and faithfully bearing witness to the Holocaust. In brief, one cannot simply read books, hear lectures on this subject, or even listen to survivors' accounts and arrive at authentic comprehension, in some part because unreflective and unprocessed receipt of information about the Holocaust can simply traumatize or re-traumatize the recipient of this knowledge in unexpected fashions. Indeed, our capacity to understand and to learn from the Holocaust might continue to elude many, at least in the fashion in which we might hope it would.

\section{The Holocaust, Ordinary Happiness, and Bearing Witness}

The tale focuses on a man named Grandpa Mendel, a widower who almost desperately desires grandchildren and a large family to compensate from the historical depredations he suffered during the Holocaust. Tragically, he happens to be a survivor of Auschwitz in an unremarkable social context in which his granddaughter Hayuta desires to relish the ordinary pleasures of her engagement party. For her part, his daughter Bella, also a Holocaust survivor, wishes for nothing more than to experience the invidious pleasures of upward social mobility and social competitiveness with her designated rival, the groom's mother, and forget the years during WWII when a Polish family hid her from the Nazis in a pigsty. However, such longing for quotidian social happiness suffers an overwhelming moral defeat at the hands or, better, the words, of Grandpa Mendel. After decades of deathly silence, "distant memories overcame those of yesterday, as often happens with old people” (Liebrecht, 1998, p. 84), ${ }^{1}$ his daughter Bella reflects. Suddenly, prompted perhaps by the presence of much food, he begins to speak volubly and graphically about his experiences in the death camps, particularly at family celebrations and religious holidays where his words cause profound uneasiness, misery, oppression, and embarrassment.

For Mandel, such speech represents traumatic access to a once wholly inaccessible past but, no less than the speaker, can traumatize the hearer and bring up matters with which they have not dealt. As Israeli psychiatrist Dori Laub attests:

While historical evidence to the event that constitutes the trauma may be abundant and documents in vast supply, the trauma—as a known event and simply as an overwhelming shock—has not been truly witnessed yet, not been taken cognizance of. The emergence of the narrative which is being listened to-and heard-is, therefore, the process and the place wherein the cognizance, the "knowing" of the event is given birth to...The listener to trauma comes to be a participant and a co-owner of the traumatic event: through his very listening, he comes to partially experience trauma in himself. The relation of the victim to the event of the trauma, therefore, impacts on the relation of the listener to it, and the latter comes to feel the bewilderment, injury, confusion, dread and conflicts that the trauma victim feels. He has to address all these, if he is to carry out his function as a listener, and if trauma is to emerge, so that its henceforth impossible witnessing can indeed take place. The listener, therefore, by definition partakes of the struggle of the victim with the

\footnotetext{
${ }^{1}$ Savyon Liebrecht, Hayuta’s engagement party. In M. Weinberger-Rotman (Trans.), Apples from the desert: Selected stories. City University of New York: The Feminist Press. Subsequent references are from this edition and will be noted parenthetically.
} 
memories and residues of his or her traumatic past. The listener has to feel the victim's victories, defeats and silence, know them from within, so that they can assume the form of testimony. (Laub, 1992, pp. 83-84)

Therefore, Mendel's desires for healing and the family's for an ordinary existence free from the traumatizing terrors of Jewish history stand at cross-purposes, especially as his family, with the exception of his daughter, refuses to participate vicariously in his traumatic experience. For as Laub explains, healing and coherent narrative require the mutual attention and cooperation of the testifier and the one who bears witness to the testimony. This short story articulates the reality that in Jewish-Israeli culture there exists no such thing as escaping from the historical memories of the Holocaust, which cause anger and resentment by intruding when and where they see "fit" and transforming conventional concerns over social propriety into instances of moral obloquy. The Holocaust shall perpetually trump matters such as common obsessions about personal social standing, which, with tragicomic irony means that the children and, particularly, the grandchildren and in-laws of Holocaust survivors seem petty, unethical, immature, and selfish, as their concerns and desires cannot possibly compete with or measure up to the vast historical black hole that constitutes the Holocaust.

\section{Holocaust Testimony Meets an Engagement Party}

As the story opens, there remain fifteen days before Hayuta's engagement party, which is arranged quickly because of the "youngsters' unexpected announcement” (Liebrecht, 1998, p. 81). In the midst of hurried, fretful planning, involving interior decoration, catering, invitations, furniture and, especially, Bella's trepidations over whether or not the dress she selects shall or shall not exhibit the same "class" of Ran's mother, her daughter's future mother-in-law, "no one had thought yet about the disgrace that Grandpa Mendel might heap upon their heads” (Liebrecht, 1998, p. 81). The somewhat inane preparations that invariably accompany such parties consume Bella and her daughter Hayuta, who, "having managed to find herself a clever and vigorous husband...from an educated and well-off family” (Liebrecht, 1998, p. 81), exacerbates their concerns about Mendel. Only after all the plans have concluded to the satisfaction of all does his daughter Bella "find the time to think about her father” (Liebrecht, 1998, p. 416). Hayuta, too, thinks about him, specifically during her final exam on Jewish history. Presuming, naturally, that Hayuta has "learned" about the Holocaust, this means, with grimly sardonic humor, that she has completely compartmentalized her education, her experience of Mendel's Holocaust speech, and her family history. She can read and "learn about" the Holocaust without these educational activities having the least impact on her anxious concerns for the success of her engagement party and worries over the "inappropriate" behavior of her grandfather Mendel. In brief, ordinary learning about the Holocaust has no impact whatsoever on her, other than to instigate her resistance inasmuch as this incomparable enormity threatens to overwhelm and sink the significance of her ordinary life and romantic plans. She wants desperately to improve her social standing by marrying someone she might love but who she does not trust to cope successfully with "difficult" matters about her family. Her underlying belief that the "Holocaust speech" of her Grandpa Mendel taints her constitutes the influence of third generation or the third hand "residue" of Holocaust experience upon her. Her apparently superficial, selfish, and heartless responses establish her and her aunt Shifra as the objects upon whom all others-including her mother Bella, and, for the most part, the reader-project their own dis-ease about bearing witness to the Holocaust through hearing the testimonies of Mendel. Hayuta will "never forgive” her grandfather if he "ruins” her engagement party, even if her own family "forgives him” (Liebrecht, 1998, p. 83) for his unwelcome testimonials during Seders or holiday meals. She does not want her fiancé's family "to get the impression that there are strange people in my 
family" (Liebrecht, 1998, p. 82), as if the family were her possession and her grandfather an oddity or "crazy" man. That the stories of Mendel are never regarded as having positive meaning or valuable, potentially healing content paves the road for her statement that she will “drop dead!” (Liebrecht, 1998, p. 83), if Mendel speaks about the Holocaust at her engagement party. Mendel annoys because his unspeakable experiences prevent other people from remaining unconscious about the frivolity of their own voluble, ludicrous chatter and romantic plans. Only Mendel, apparently, can think of marriage and the Holocaust and children and trauma in the same context—although doing so literally kills him at the end of the story because of his family's adverse reactions to his placing these incongruous things in juxtaposition.

Bella and Hayuta do not know what to "do" about Mendel, but Hayuta, in an unconscious comic allusion to the Final Solution notes that she and her mother will need to "find some solution" (Liebrecht, 1998, p. 83). Hayuta, representing herself traumatically as the person to despise in this story, recommends that they send Mendel away on one of the "trips the municipality is organizing for senior citizens" (Liebrecht, 1998, p. 83). Bella now pleads that Mandel could be persuaded upon to "control himself” (Liebrecht, 1998, p. 83), but Hayuta is convinced that "talking's not going to help” (Liebrecht, 1998, p. 83)—a patently false statement. Her mother now hits upon the solution of having her daughter-in-law Shifra, who has no patience for Mendel, sit next to him and prevent him from talking. When Hayuta continues to insist that they exile her Grandpa from the party, Bella, disgusted and out of patience, exclaims that "they"—-meaning she and Israeli society—appears to have raised heartless children:

Monsters, thought Bella in disgust as her daughter went to answer the phone. We are raising monsters. At first they look like babies, then like children, but behind the innocent façade—-hearts of stone! I've heard of children throwing their old folks into the streets, waiting for them to die. Just like that- to shamelessly evict Grandfather from your engagement party! (Liebrecht, 1998, p. 417)

Whether or not the author also alludes to the effects of living with the other traumas of Israeli society—what with perpetual warfare and strife over secularism or religious observance of Judaism, Bella makes stereotypical complaints against the younger generation and, in doing so, manages to evade consideration of her relationship to her own Holocaust experiences, which she has not communicated to her daughter or father Mendel. Hayuta, for her part, has no preparation for her act of witnessing testimonies, and therefore, while far from commendable, her aversion to the Holocaust appears at least understandable, especially since she had not, at an earlier age, bonded with her mother or Grandpa over these stories. Her responses raise important questions about whether the stories of the Holocaust will live on or die out with the second generation. The story strongly implies they will not, which, if suspected by Mendel as his life draws to a close, gives further impetus to his speech. His wants his experiences to be remembered and understood, so that, at the very least, his family can appreciate the plenty they enjoy and the dangers that continue to threaten them from anti-Semitism.

Indeed, after her daughter leaves and Bella confronts her own ambivalent feelings and memories, she admits that having Mendel present "would cause a disaster at the party” (Liebrecht, 1998, p. 84). She reflects that, "at the sight of food," words "just gushed from his mouth, beyond his control” (Liebrecht, 1998, p. 84). Although Bella fails to explicitly connect the sight of food with his experiences of near starvation in the concentration camps, she nonetheless begins the work of piecing together her remembrances, which her father's speech has facilitated. Bella also notes that, up until recently, Mendel had remained silent and therefore "was 
really in good shape” (Liebrecht, 1998, p. 84). While the onset of old age and the prospect of dying can elicit memories long repressed, it is also true that memorialization is far healthier than amnesia, so Bella misreads the consequences of silence, both for herself and for her father (Kellermann, n.d.). Bella segues unconsciously into remembrances of the time at the end of the war, when she was a young girl, and she only barely recognized her father's "emaciated" face and his protruding nose and cheekbones (Liebrecht, 1998, p. 84), and does not see in her father a man suffering from excruciating hunger. Mendel had bent down to hug his children, Mordechai and Bella, and promised, "We'll forget everything, everything. We'll look for Mother and then we'll go to America" (Liebrecht, 1998, p. 84). However, Mother has perished and they end up in Israel, with its atmosphere of public traumas from terrorism and perpetual public remembrances of the Holocaust. Regardless of these many commemorations, however, Bella and her brother never ask their father about his experiences during the Holocaust—or give voice to their own—and, following Mendel, have "vowed to force those memories into oblivion" (Liebrecht, 1998, p. 85). Mendel, too, had retained his silence until, six years earlier, some random concatenation of sensations-and traumatic memories have such an unbidden, random, temporally disconnected character — caused something inside him to "buckle" (Liebrecht, 1998, p. 419), and the memories to pour out of him. ${ }^{2}$ During Rosh Hashanah dinner, Mendel tells tales of not eating meat for years; of looking like a skeleton; of hearing rumors about the Americans that make the Germans nervous; and of a starving man bolting down a sausage and falling “down dead” (Liebrecht, 1998, p. 85). His family looks at him "aghast,” and, given the fact that trauma means feeling overwhelmed by and unprepared for an experience of horror-become traumatized. The memories of these stories manage to fade over the course of the evening, but after dinner, Mendel starts in again with even more traumatic stories: Men who died in the barracks and began to smell in the morning, and how one day he found a potato in the pocket of a cold dead man. Mendel, wondering how in the world the dead man came into possession of this potato, given the fact that he did not work in the kitchen, appears acutely traumatized by this particular nonsensical remembrance. "Where did he get that potato?” asks Mendel in wonder.

\section{Holocaust Exhaustion}

Over the six years separating the onslaught of traumatic Holocaust memories from the engagement party, their hearts become "hardened" (Liebrecht, 1998, p. 420). On Shabbat, holidays, and birthdays, Mendel diverts attention away from family happiness with his testimonies. Tales of people who drop dead in the ghetto; tales of people trampled and robbed of their shoes; tales of people who die of starvation or throw themselves onto electrified fences; tales of a man who finds the garb of his wife and of a German, suspecting him of theft, lashing him on his neck; and tales of a young boy who carried bodies to the crematorium and found his mother among the dead. The family attempts to ignore his words, allowing Mendel to talk, but blocks "his stories from the path to their hearts” (Liebrecht, 1998, p. 87). The family, having now acquired a case of secondary Post Traumatic Stress Disorder, experiences numbness, and the terrible knowledge that the world lacks fairness and that the most appalling disaster can overtake human lives at any time. However, the family resigns themselves to suffer this onslaught-these "descriptions of hunger, death, and putrefaction" (Liebrecht, 1998, p. 87)—while Shifra, his daughter-in-law, eventually rises against Mendel and her in-laws in impatient rebellion:

\footnotetext{
${ }^{2}$ While it is true that ancillary traumas such as the onset of old age, sickness, and the prospect of death can elicit earlier traumatic recollections, it is impossible to say, finally, what causes anyone to begin to speak about the Holocaust after having retained a studied silence for decades.
} 
We have suffered enough, and we've heard enough. Don't we have Memorial Day and Holocaust Day and memorial assemblies and what have you? They never let you forget for a moment. So why do I need to be reminded of it at every meal? I don't understand how you can go on eating so heartily when he goes on and on about festering wounds, blood, and vomit—but that's your own business. (Liebrecht, 1998, p. 88)

Shifra slams her fist down on the table in angry exacerbation, and while she sincerely believes she has "suffered enough", she cannot imagine the suffering actually involved in the Holocaust. Indeed, the mention of this topic terrifies, exhausts, and sickens her, as she does not have the experience, the training, or the childhood experience with Mendel to make her empathetic. However, Bella, in revelatory illumination of the mysteries of her own life, begins to actually listen to her father Mendel. Soon, a window into her own experience opens-a "key to the riddle that had haunted her all these years" (Liebrecht, 1998, p. 88). She wonders if her father, unlike she and, one must presume, her brother, "had erased from his memory everything that had happened to him in the four years she and her brother spent in the pigsty of the Polish peasant” (Liebrecht, 1998, p. 421). However, her memories, which she has never shared with her children, rush back as she listens to her father:

For a few moments she found herself walking in the village roads, smelling the sty as if it were a reality and not a distant memory. She felt the wet snouts of the piglets in the palm of her hand, their skin hardened with mud. Had her father forgotten the death and the fear and the hunger? How would he lock them in his heart and never mention them for forty years? And now, how had his locked memories awakened in him, in the presence of all the abundance and the songs and the conciliatory atmosphere that permeates the illuminated rooms on holidays? It's a psychological mystery, Bella concluded, whose resolution can perhaps be found only at the level at which man is totally denuded —he will take it with him to his grave. (Liebrecht, 1998, p. 88)

Apparently unbeknownst to Bella, many survivors in Israel began to speak approximately forty years after the Holocaust for numerous reasons: An earlier Israeli contempt for European Jews who had presumably allowed themselves to be led to the gas chambers like "animals to the slaughter" had given way to appreciation and understanding; the traumas of illness and approaching death that prompted earlier traumatic memories for Holocaust survivors; and, at last, as Bella suggests, the unexplored mysteries of human psychology. Unconscious over her conflict regarding her own memories-and certainly not willing or able to share experiences that no one wants to hear about at all events-she hovers between believing that they cannot possibly not invite Grandpa to the engagement party on the one hand and fearing that he will ruin the whole party, perhaps the future of her daughter, and "cause the family to irrevocably lose face in front of all the guests" (Liebrecht, 1998, p. 88) on the other. If Hayuta and Shifra represent disconsolate resentment at the irruption of traumatic senselessness into their conventional and predictable life plans, then Bella represents irremediable conflict between the claims of the past and the present.

The problem of what to "do" with Mendel becomes resolved when Hayuta herself speaks to him. Shifra agrees to hush Mandel and Hayuta informs him that telling his stories will ruin her engagement party. She even extracts from him a seriocomic promise to remain quiet and only say (ironically) Le Chaim! When the party actually arrives, Bella compares herself favorably with the stylish mother-in-law with whom she has had a passionate competition since the beginning of the story. Overjoyed that Mandel is present yet controlled, and that she has an occasion for ordinary and non-traumatic family enjoyment, Bella has the privilege-rare in her life-to experience "a happiness almost palpable” (Liebrecht, 1998, p. 90). However, Hayuta then notices her father Mendel with the look that presages him telling his Holocaust memories. She "pierced him with her harsh 
look" (Liebrecht, 1998, p. 424). Mendel smiles mischievously, like a boy caught in a "bad" act, and repeats his approved line: Le Chaim! All continues pleasantly and cheerfully until Hayuta again notices the excitement on Mendel's face, who stands by the meat and cake- two items that, along with the customary family celebration, he had not known during his four years at the death camp. He thumps on the table to prepare to speak. Hayuta yells out, “Grandpa, no!” (Liebrecht, 1998, p. 425). She tears herself from the arms of her fiancé Ran. She finds that Mendel, aghast at being censored, has collapsed under the broken table amidst the food. Hayuta and her mother Bella repair to the room to which Mendel has been taken, and Hayuta gives her mother napkins with which to dab her streaming face and the frosting-coated face of Mendel. Bella has a sudden terminal realization:

Then she took another tissue and very gently, as if she could still inflict pain, wiped the anguished face which knew no final release, and the handsome mustache, and the closed eyes, and the lips that were tightly pursed under a layer of sweet frosting, firmly treasuring the words that would now never bring salvation, not conciliation, not even a momentary relief. (Liebrecht, 1998, p. 425)

Bella, looking over her father with her daughter Hayuta, the former who appears to have had a stroke, wipes his face very gently, as if he were alive and she could "still inflict pain”. But Mendel appears mercifully beyond pain, although, in the estimate of Bella, this can be true only on the physical level, for his "anguished face” knew "no final release”. His lips, Bella imagines, are "tightly pursed”, treasuring words that, at this stage, cannot bring salvation, conciliation, or even relief. His words came too late, and were uttered to an audience not prepared to listen, as the Holocaust remains too close, too terrible to handle or transmit even for the second generation, who are more affected by it than Bella, Mordechai, and Mendel.

\section{Conclusion}

We are all born into some story, with its particular background relief that profoundly affects our physical, emotional, social, and spiritual growth, independence, and maturation. In the case of the children of Holocaust survivors, whether of the second or third generation, the background story tends strongly either to exist as an existential mystery, as Bella says of the psychological motivations Mendel has for beginning to speak, or overflowing with traumatic information that, as seen in Hayuta and Shifra, cannot be assimilated or understood. In the first case the child of the survivor might feel exhausted but in need of information, and in the second case overwhelmed and horrified with the idea of knowing even more. Rather than casting judgment on her characters, this story suggests that we consider how we are positioned in relationship to the Holocaust, and how radically incongruous our positioning must invariably be.

\section{References}

Brockmeier, J., \& Carbaugh, D. (Eds.). (2001). Narrative and identity: Studies in autobiography, self and culture. New York: Johns Benjamin Publishing Company.

Fackenheim, E. (1994). To mend the world: Foundations of post-holocaust Jewish thought. Bloomington, Indiana: Indiana University Press.

Kellermann, N. P. F. (n.d.) Long term psychological effects and treatment of holocaust trauma [PDF document]. Retrieved from http://peterfelix.tripod.com/home/Ho.pdf

Laub, D. (1992). Bearing witness or the vicissitudes of listening. In S. Felman \& D. Laub (Eds.), Testimony: Crises of witnessing in literature, psychoanalysis, and history. New York and London: Routledge.

Liebrecht, S. (1998). Hayuta's engagement party. In M. Weinberger-Rotman (Trans.), Apples from the desert: Selected stories. City University of New York: The Feminist Press. 
O’Laughton, M. (Ed.) (2014). The ethics of remembering and the consequences of forgetting: Essays on trauma, history, and memory. New York: Rowman and Littlefield Publishers.

Spago, R. C. (2006). Emmanuel Levinas, the holocaust, and the unjust death. Baltimore: Johns Hopkin University Press.

Wiesel, E. (2002). After the darkness: Reflections on the holocaust. New York: Schocken Press. 